\title{
Inequality in Public Decision Making Process: Case Studies of Cement Factories in Central Java, Indonesia
}

\author{
Sudharto P. Hadi ${ }^{1, *}$, Hartuti Purnaweni ${ }^{1}$, Kismartini Kismartini ${ }^{1}$ \\ ${ }^{1}$ Faculty of Social and Political Sciences, Universitas Diponegoro, Semarang - Indonesia
}

\begin{abstract}
North Kendeng mountain in Central Java is rich in limestone potentially utilized for cement and other uses. It is also a storage of ground water currently being utilized for potable water and rice field's irrigation. Conflict on North Kendeng Mountain revolves around the utilization of limestone for mining or for conservation. This paper reviews the process of decision making through EIA studies done and spatial planning. The type of research is descriptive analysis. The data gathered through document and content analysis, physical and social observation and informal interview with relevant interests. The data obtained was analyzed quantitatively and qualitatively. In the District of Sukolilo, Pati Regency, EIA as basis for issuing environmental permit for cement factory was considered did not address the critical issue regarding the number of spring water potentially affected by Cement Factory activities. While the decision on determining KBAK (natural landscape of karst) Sukolilo need to be conserved created controversy. It is the fact that the KBAK area become narrowed than the previous stipulation. In addition, the area determined as non-KBAK at TambakromoKayen, utilized for mining, has similar characteristics of the area determined as KBAK. To ensure the sustainability of utilization and management of North Kendeng Mountain, it is required a transparence, participative and objective decision making process.
\end{abstract}

Keywords: Kendeng Mountain, Exploitation, Conservation, Inequality, Decision Making Process

\section{Introduction}

Based on UN publication (2000), public participation pillar divided into three pillars. The first part concerns participation by the public that may be affected by or is otherwise interested in decision making on a specific activity [1]. The second part concerns the participation of the public in the development, plans, programs and policies related to the environment. The third part concerns the participation of the public in the preparation of laws, rules and legally binding norms.

\footnotetext{
${ }^{*}$ Corresponding author sudhartophadi@yahoo.co.id
}

Act no 32 of 2009 on Environmental Management and Protection Act, article 70 stipulates that every person has the right and the same opportunity to widely and actively play a role in the protection and environmental management. The role of community is in the form of (a) social control, (b) providing suggestion, opinion, proposal, objection, complaint and/ or (c) delivering information and/ or report. It is further explained that public participation is conducted to (a) improve the concern on environmental protection and management, (b) to improve self reliance, empowerment and partnership, (c) to nurture the ability and pioneer of community, (d) to nurture immediate response for social control, and 
(d) to develop and to maintain culture and local wisdom for sustaining environmental carrying capacity

The process of decision making in determining spatial planning, feasibility of Environmental Impact Assessment (EIA) and issuing environmental permit on the utilization of North Kendeng must involve local residents for two reasons. Firstly, this plan and program will affect people's life. Secondly, the plan and program must reflects the aspiration, need and concern of local people. This paper reviews how local people involved in EIA, environmental permit and spatial planning process on the decision making of the utilization of Kendeng Mountain.

\section{Methodology}

Puaschunder explains that one driving factor of decision is called availability in which which individuals primarily focus on available and present information making the decision bias [2]. LlopisAlbert, et al note that the pressures on water resources are driven by human activity, population growth, living standards increase, land-use and climate changes, growing competition for water, and pollution from industrial, municipal, and agricultural sources threaten. Sustainability [3]. Llopis-Albert et al further suggest that it is necessary to make a balance between environmental damage cost and benefits of the water for region's sustainable socio-economic development ${ }^{3}$. In many cases, the benefit could not compensate the environmental lose.

Kerkho, Lorrae van and Victoria Pilbeam suggest that science should have a stronger influence in environmental decision-making. In many cases, people face unnecessary hardship because of failing to address the challenges posed by environmental change [4]. They further explain that between science and decision making is very complex. It needs to build an understanding of public knowledge. One way to connect the political and scientific aspects of environmental decision-making is to make informed choices about the ways in which interventions seek to shift the power. While the framework may be used analytically to facilitate understanding and critical reflection, it may also be used to carefully consider the questions of whether and to what extent those interventions challenge or accommodate existing knowledge governance structures.

Sigel, et al note that environmental decisionmaking has a problem of uncertainty due to diversity of nature, dynamic natural processes involved, many complex interactions between nature and human beings [5]. They suggest that good solutions for environmental problems require a large amount of knowledge as a solid foundation for decision-making, however the knowledge available is fragmentary and not systemized

\section{Discussion}

The plan to build a cement factory was initiated in 2006 in the district of Sukolilo by P.T Semen Gresik, a state owned company and was opposed by local people pioneered by Adat or Traditional People called Sedulur Sikep or Samin. The reason for opposing this plan is that Kendeng Mountain is a storage of water resources for irrigation of hundred hectare of rice field and for household use. However, spatial planning of Pati Regency for the period of 2011-2031 allocated this area for mining without being accompanied with adequate public consultation as required by Act 26 of 2007 on Spatial Planning. Article 65 of This Act stipulates that the role of community in spatial planning consist of participation in formulation, utilization and control. They have the right to sue to the court if they are harmed by spatial planning. EIA for Cement Factory in Sukolilo as a tool of planning did not also incorporate the aspiration, need and concern of local people. Based on EIA studies done by a consultant, only 5 non-permanent spring water predicted to be affected by a project while local people found that 41 spring water will be adversely affected by a project. However this EIA was used as basis for issuing environmental permit.

In the districts of Tambakromo and Kayen, Pati Regency where the private cement factory will be built, the issues revolve around the width of KBAK (Karst Natural Area) need to be conserved and the siting of proposed cement factory. Gunretno, the head of Adat People Sedulur Sikep, mentioned at Focus Group Discussion initiated by Suara Merdeka Newspaper on August 14, 2014 in Kudus, Central Java, that the area of KBAK in 2005 reach 11.000 hectare and become 7000 hectare in 2008 , and it has been codified with Ministerial Decree of Energy and Mineral Resources No 2641 of 2014.

The site of proposed private cement factory which formally located at non-KBAK area, based on local people observation, it was found that this area has a similar characteristics with the area determined as KBAK. This is parallel with Paripurno et al findings that at the site of proposed cement factory there are five sinkhole (ponor) [6]. Paripurno et al further explain 
that there are 25 mouths of cave and 30 spring water at the proposed mining area. With this phenomena it can be concluded that both decision on narrowing the KBAK area and the siting of cement factory did not provide room for participation for local people. Consequently, these policies spark conflict and local people resist to oppose the policies.

If this phenomenon is framed by Arstein's theory of ladder of citizen participation, can be categorized as informing meaning that the government involve the public to participate when the policy and program at the late stage of planning or when it almost ready [7]. Borrowing Kerkho's term it is a fact that people face a hardship because of inability of decision making to address their concern [4].

\section{Conclusion}

The policy, program and project in certain area, in addition to create positive impacts, will also adversely affect the life of local people. It is compulsory for project proponents to involve local people at the earliest stage of planning. Lesson from the case of Pati Regency show that failing to involve people spark the conflict between local people supported by academician and NGOs on one side and factories and the governments and other side. Internal conflict between local people also occur. It is necessary to involve people substantially meaning that relevant inputs need to be accommodated at the decision making. In addition, the involvement must be done at the earliest stage of planning and incorporate the representativeness of local people.

\section{References and Notes}

1. United Nations, Economics Commission for Europe, "UN Convention on Access to Information, Public Participation in Decision Making and Access to Justice in Environmental Matters", The Aarhus Convention: An Implementation Guide, Geneva, United Nations (2000).

2. J. M. Puaschunder, "Ethical decision making under social uncertainty: An introduction to Überethicality Sustainable Production and Consumption", 12 78-89 (2017).

3. C. Llopis-Albert, D. Palacios-Marques and P. SotoAcosta, Journal of Business Research. 6816 411644 (2015).

4. L. V. Kerkho, and V. Pilbeam, Environmental Science and Policy, A knowledge governance approach, 73, 29 (2017).

5. K. Sigel, B. Klauer and C. Pahl-Wostl, , Ecological Economics, 69 502-510 (2010).

6. E. T. Paripurno, S. Wijanarko and F.A. Choirudin, "Nilai Penting Ponor, Gua dan Mata air dalam Sistem Kars Kendeng Kasus Ekosistem Karst Kayen dan Tambakromo Kabupaten Pati”, Pusat Studi Manajemen Bencana UPN Veteran, Yogyakarta (2014).

7. S. R. Arstein, APA Journal 35 216-224 (1969).

8. Ministry of Environment, Republic of Indonesia Act 32 of 2009 on Environmental Protection and Management (2009).

9. Ministry of Public Work, Republic of Indonesia Act 26 of 2007 on Spatial Planning (2007). 